\title{
A HERMENÊUTICA FILOSÓFICA É FILOSOFIA PRÁTICA?
}

\author{
IS PHILOSOPHICAL HERMENEUTICS PRACTICAL \\ PHILOSOPHY?
}

Rainri Back dos Santos*

Recebido: 04/2017 Aprovado: 10/2017

\begin{abstract}
Resumo: O objetivo geral é apresentar algumas boas razões para se contrapor ao projeto de Gadamer de considerar a hermenêutica uma filosofia prática. Para tanto, o ensaio primeiro procura mostrar quais razões Gadamer apresenta para caracterizar assim a hermenêutica. Então, o passo seguinte é demonstrar a insuficiência de tais razões, sobretudo, porque a hermenêutica se recusa a fazer o que cabe a uma filosofia prática: ser útil a alguém. Por fim, são apresentadas três pressuposições da perspectiva de Gadamer às quais podem ser contrapostos três posicionamentos críticos.
\end{abstract}

Palavras-chave: hermenêutica; filosofia prática; aplicação; ser útil.

\begin{abstract}
The overall aim is to present some good reasons against the Gadamer's project of considering hermeneutics as practical philosophy. For this, this essay seeks to show what reasons Gadamer presents to characterize hermeneutics in such a way. So the next step is to demonstrate the insufficiency of such reasons, especially because hermeneutics refuses to do what a practical philosophy has to do: to be useful to someone. Finally, it can be presented three critical positions against three presuppositions of Gadamer's perspective.

Keywords: hermeneutics; practical philosophy; application; to be useful.
\end{abstract}

\section{Apresentação do problema}

Em 2002, o prof. Ernildo Stein publicou, na revista Filosofia Unisinos, um artigo intitulado "É a hermenêutica filosófica filosofia?". Como o título já sugere, a finalidade primordial do texto é duvidar do estatuto filosófico que Gadamer atribui à hermenêutica em Verdade e método. Para Stein, a dúvida se justifica, pois Heidegger, de cujo pensamento a hermenêutica filosófica procede historicamente, afirmara de modo categórico: "a hermenêutica não é filosofia" (HEIDEGGER apud STEIN, 2002, p. 73). Para Heidegger, a hermenêutica seria apenas um adjetivo da filosofia, como o confirma gramaticalmente a expressão "filosofia hermenêutica". Gadamer, por sua vez, transforma a hermenêutica em substantivo, como o indica a expressão "hermenêutica filosófica", o que, segundo Stein, atesta uma mudança significativa no estatuto da hermenêutica. Justamente aí incide a dúvida de Stein: tal mudança se justifica?

Obviamente, não é possível fazer jus, passo a passo, à complexidade da exposição de Stein, mas me parece viável pelo menos pontuar os momentos mais importantes graças aos quais ele fundamenta a conclusão do artigo. Primeiro, é importante apresentar as razões de Heidegger para não considerar a hermenêutica ela mesma uma filosofia, todas elas expostas em Ontologia (Hermenêutica da facticidade). Enquanto a palavra 'facticidade' denomina o ser

Doutorado em Filosofia (UERJ). Filiação institucional: Universidade de Brasília. E-mail: rainribach@yahoo.com.br

Problemata: R. Intern. Fil. v. 8. n. 3 (2017), p. 78-102 ISSN 2236-8612

doi:http://dx.doi.org/10.7443/problemata.v8i3.33782 
mesmo do ser-aí (Dasein), caberia à hermenêutica, na condição de hermenêutica da facticidade, apenas explicitá-lo o ser do ser-aí. Mas hermenêutica e facticidade mantêm entre si uma relação que extrapola aquela relação tradicional em que uma teoria, a hermenêutica, se volta para certo objeto, a facticidade: a hermenêutica é em si mesma um modo de ser da própria facticidade!

Bem aqui, é absolutamente decisivo expor a razão pela qual Heidegger considera a hermenêutica "algo provisório", pois aí se condensa, creio, toda a justificativa para não considerá-la filosofia. Todavia, o que dificulta bastante a interpretação é a maneira lacônica e vaga como Heidegger se exprime em uma passagem crucial: "A hermenêutica", diz ele (loc. cit.), "permanece desimportante enquanto não está 'aí' o estar desperto para a facticidade que ela deve temporalizar". Ora, a hermenêutica não parece ser importante, porque ela só pode fazer o que lhe cabe caso seja satisfeita uma condição: caso o ser-aí já esteja desperto para a facticidade! Tal despertamento é uma transformação na existência fática e decorre do modo como o ser-aí lida com a própria morte, sobre o qual a hermenêutica não parece ter influência alguma.

Então, o que lhe resta fazer? Ela seria apenas o âmbito a partir do qual o ser-aí - uma vez desperto - poderia investigar mais propriamente o que uma ontologia bem fundamentada deveria investigar: o próprio ser do ser-aí. Não por acaso, Heidegger adverte: embora a hermenêutica seja "algo provisório", "o que importa não é libertar-se dela mais rápido possível, mas perseverar nela possivelmente muito [...]" (Ioc. cit., grifo nosso). A hermenêutica é apenas a perspectiva desde qual o ser-aí desperto compreende a própria facticidade e onde ele deve se manter tanto quanto lhe for possível. De maneira geral, a hermenêutica não seria filosofia, de acordo com Heidegger, porque lhe caberia apenas a tarefa de "exibir aos filósofos de hoje um objeto até agora caído no esquecimento" (HEIDEGGER apud STEIN, ibid., p. 73).

Então, qual seria a razão de Gadamer para considerar a hermenêutica como filosofia? Aqui, Stein se baseia nas próprias palavras de Gadamer: "Talvez soe paradoxal", diz ele (GADAMER apud STEIN, loc. cit.), "que justamente estejam na base do desenvolvimento do problema hermenêutico que eu empreendo a crítica heideggeriana da postura transcendental e seu pensamento da 'viravolta' (Kehre)". Para deixar tudo mais claro, o projeto de Gadamer, segundo ele mesmo testemunha, consiste em erigir uma hermenêutica filosófica a partir da fusão de dois momentos do pensamento de Heidegger. Assim, ela, a hermenêutica, se ancora em uma articulação das reflexões do "jovem Heidegger" sobre a facticidade da existência com as reflexões da fase mais madura do pensamento de Heidegger sobre a história do ser. Enfim, a dúvida de Stein pode ser reelaborada da seguinte maneira: tal articulação é legítima?

Ora, Gadamer mesmo parece ter plena consciência da dificuldade de legitimá-la, uma vez que ele próprio admite a possibilidade de "soar paradoxal" a 
articulação entre as duas fases do pensamento de Heidegger. Porém, Stein parece levar bastante a sério - a sério demais, talvez - a intenção de Gadamer de "seguir" Heidegger, a ponto de se perguntar pela coerência entre o que Heidegger pensou e o que ele, Gadamer, passou a pensar. Em dado momento, Stein (ibid., p. 80) até reforça a condição meramente adjetiva da hermenêutica e o fato de a fenomenologia ser muito mais um "procedimento", o que impossibilitaria considerá-las "áreas de conhecimento" autônomas. Então, parece fazer sentido a dúvida: como Gadamer poderia "seguir" Heidegger, se ele confere à hermenêutica o título de filosofia, o que Heidegger jamais fez?

Bom, até aqui, não vejo nenhuma razão suficientemente forte para a censura de Stein ao projeto de Gadamer, até porque, como Stein (ibid., p. 81) mesmo admite, há várias maneiras de "seguir" alguém; 'seguir' não precisa significar 'ser rigorosamente coerente com o que pensa aquele que está sendo seguido'. Mesmo assim, Stein parece insistir na mesma linha de argumentação ao passar para o último tópico do artigo, onde aborda aquela que, segundo ele, deve ser considerada a grande questão da filosofia: o conhecimento. Primeiramente, Stein (ibid., p. 82) defende uma interpretação, no mínimo, curiosa: Heidegger escreveu Ser e tempo, diz ele, com o intuito de solucionar o problema do conhecimento, ${ }^{1}$ o que deveria ser considerado uma "evidência", como ele ainda enfatiza. Gadamer, por sua vez, perde de vista essa suposta finalidade da ontologia fundamental, quando se dispõe a delimitar "uma verdade de caráter muito particular na arte, na história e na linguagem [...]" (ibid., p. 83).

Mais uma vez, o que deveria legitimar uma hermenêutica filosófica seria a coerência dela com o projeto originador da ontologia fundamental de Heidegger, da qual Gadamer manifestamente se considera sectário. Por enquanto, tal incoerência ainda não parece tocar o ponto fundamental do problema, a saber, a solidez de um fundamento híbrido composto pela articulação das duas fases bem distintas do pensamento de Heidegger. Quando toca em tal ponto, a argumentação de Stein se torna, para mim, muito vaga. Aquela paradoxalidade do projeto fundador da hermenêutica filosófica, admitida até por Gadamer em Verdade e método, se deve, segundo Stein (ibid., p. 84), à tentativa de conjugar "elementos contraditórios". Mas quais seriam tais "elementos contraditórios"? Eis a passagem mais esclarecedora do artigo de Stein:

Seu nascimento [da hermenêutica filosófica], suas bases trazem elementos contraditórios. É por isso que ela oscila entre uma espécie de teoria da experiência hermenêutica do sentido e um conhecimento que não se quer condição de possibilidade de conhecimento em geral, e seria só, nesse caso, ligada ao problema filosófico do conhecimento. (STEIN, 2002, p. 84, grifo do autor). 
Para reconstruir a argumentação de Stein de um modo mais claro, é necessário mostrar como uma "teoria da experiência hermenêutica do sentido" contradiz uma investigação sobre as condições de possibilidade do conhecimento em geral. Aparentemente, uma teoria da experiência hermenêutica do sentido, segundo Stein, se encarregaria de delimitar aquela "verdade de caráter muito particular na arte, na história e na linguagem [...]" (ibid., p. 83). Já uma investigação transcendental, interessada nas condições de possibilidade do conhecimento em geral, visa a verdade como tal, ao contrário do que pretende uma teoria da experiência hermenêutica do sentido. Ora, convém perguntar finalmente: onde está a contradição, visto que a hermenêutica filosófica, como Stein (ibid., p. 83) mesmo observa, não mais mira "o que a fenomenologia pretendia, isto é, uma base para a pretensão de validade do conhecimento"?

Para haver contradição em um ponto de vista, quem o defende precisa buscar a conjugação de dois aspectos que não admitem conjugação alguma, o que não parece ser o caso quando se trata de Gadamer. Daqueles dois "elementos contraditórios" aos quais Stein se refere, a hermenêutica de Gadamer claramente não se compromete com um deles, qual seja, encontrar um fundamento que valide indubitavelmente o conhecimento. E não seria demais reforçar: até mesmo Stein reconhece a falta de compromisso da hermenêutica de Gadamer com esse projeto da fenomenologia! Portanto, se estiver correta a interpretação do argumento de Stein apresentada no parágrafo anterior, não pode haver contradição alguma na hermenêutica filosófica! Afinal, nela falta um dos aspectos motivadores da contradição mencionada, de modo que, sem ele, se desfaz imediatamente o conflito característico de uma contradição.

Ademais, se Heidegger encontra no projeto da fenomenologia a motivação para escrever Ser e tempo, ${ }^{2}$ Gadamer não precisa levá-lo adiante para, só assim, justificar a sua concordância com aspectos importantes da filosofia hermenêutica de Heidegger. A propósito, quando Stein (ibid., p. 81) compreende a filosofia como "uma grande disciplina que trata do conhecimento", ele parece partir de uma pressuposição cujo alcance ultrapassa a polêmica com a hermenêutica filosófica. Ora, para desenvolver uma filosofia, ninguém precisa partir do velho problema do conhecimento, ${ }^{3}$ pois, do contrário, talvez deixasse de ser filosofia a maioria do pensamento desenvolvido no século XX. Enfim, as descobertas de Heidegger podem muito bem ter inspirado Gadamer a pensar a hermenêutica de outra maneira, deixando-se influenciar, inclusive, por outras fontes, o que poderia ser outro significado da expressão "seguir alguém"!

Finalmente, tudo o que expus até aqui parece cumprir bem o seu propósito neste ensaio, de modo que convém agora justificar por que o começo com tais considerações sobre o artigo do prof. Ernildo Stein. Eu e ele miramos uma finalidade comum: questionar o estatuto que Gadamer confere à hermenêutica filosófica. Eu, por minha vez, não vejo nenhum problema em a hermenêutica se 
considerar filosofia, e até poderia apresentar aqui algumas razões para justificála. Porém, o escopo deste ensaio é bem outro. O que pretendo apresentar aqui é algumas razões, boas razões, espero, para contestar a pretensão da hermenêutica de se considerar filosofia prática! Decerto, para negar o título de filosofia prática à hermenêutica filosófica, me parece indispensável esclarecer por que, segundo Gadamer, a hermenêutica pode ser assim caracterizada. Afinal, é aí que principia todo o problema. Eis, portanto, o tema da próxima seção.

\section{Por que a hermenêutica filosófica seria filosofia prática?}

Para responder à pergunta que intitula e motiva esta seção, a exposição seguinte precisa obedecer a um roteiro bem definido, haja vista a finalidade geral deste ensaio. Primeiro, é necessário apresentar os aspectos mais fundamentais do elemento estruturador da experiência hermenêutica, a saber: a aplicação (Anwendung). Por quê? Ora, porque ela proporciona a Gadamer o fundamento graças ao qual lhe parece possível justificar a caracterização da hermenêutica como filosofia prática. De modo geral, a hermenêutica seria filosofia prática, pois a coisa nela investigada, a compreensão, é ontologicamente muito semelhante à coisa investigada na ética, a ação; e a aplicação é justamente o que fundamenta a similaridade entre ambas, compreensão e ação. Uma vez constatada e fundamentada a semelhança, estaria suficientemente justificada a inclusão da hermenêutica no âmbito da filosofia prática, junto com a ética e a política.

Mas, enfim, o que Gadamer entende por 'aplicação'? É fundamental esclarecê-lo, pois o uso comum da palavra já viciou o seu significado. Em uma aproximação geral, bem geral, o que Gadamer chama de aplicação é aquilo que sempre estruturou a experiência da compreensão. ${ }^{4}$ Até quando a hermenêutica não passava de uma disciplina técnica, fragmentada em diversos ramos, a aplicação nunca deixou de ser a estrutura mesma da compreensão. Na hermenêutica teológica, o problema não consistia em saber apenas como interpretar a Bíblia, mas sim como professar a fé; na hermenêutica filológica, a cultura clássica não impunha aos intérpretes humanistas um mero problema de tradução, pois o que estava em questão eram conceitos distintos de humanidade; na hermenêutica jurídica, muito menos, o debate não se resumia a como interpretar as antigas leis, mas sim concernia a como cultivar o próprio direito!

Então, qual seria o aspecto estruturante pelo qual seria possível encontrar algo comum entre as disciplinas precursoras da hermenêutica filosófica, embora cada uma lidasse com uma questão muito distinta das outras? Ora, nem a teologia nem a filologia nem a jurisprudência poderiam impedir que os textos interpretados arrogassem para si a pretensão de considerar verdadeiro o que eles 
diziam a respeito das coisas sobre as quais versavam. - A necessidade incontornável de lidar com tal pretensão de verdade de um texto qualquer, caso o intérprete almeje realmente compreendê-lo, é o que Gadamer chama de aplicação. Mas por que "aplicação"? Apenas porque quem interpreta um discurso precisa fazer valer, durante a interpretação, a maneira como ele, o discurso interpretado, Ihe apresenta as coisas sobre as quais versa.

Trata-se de um aspecto necessário a qualquer compreensão, pois a quem ignora a pretensão de verdade de um discurso não lhe resta outra experiência senão a mera audição ou o simples pronunciamento dos sons de palavras. Em tal caso, não haveria interpretação, visto que, se alguém Ihe perguntasse: "O que a senhora entendeu do que acabou de ler (ou ouvir)?", ela talvez respondesse algo assim: "Perdão! Não prestei atenção no texto. Preciso lê-lo novamente". Em outras palavras, é necessário aplicar a si mesmo o que o discurso diz; é necessário ver as coisas sobre as quais versa o discurso interpretado tal como ele as vê, tal como ele as mostra ao intérprete. Não por acaso, Gadamer considera a aplicação o "problema fundamental da hermenêutica", o que pode ser confirmado na seguinte passagem de Verdade e método:

[...] a aplicação não é uma parte última, suplementar e ocasional do fenômeno da compreensão, mas o determina desde o princípio e no seu todo. Também aqui a aplicação consistia em relacionar algo geral e prévio com uma situação particular. O intérprete que se confronta com uma tradição procura aplicá-la a si mesmo. Mas isso tampouco significa que, para ele, o texto transmitido seja dado e compreendido como algo de universal e que só assim poderia ser empregado posteriormente numa aplicação particular. Ao contrário, o intérprete não quer apenas compreender esse universal, o texto, isto é, compreender o que diz a tradição e o que constitui o sentido e o significado do texto. Mas para compreender isso ele não pode ignorar a si mesmo e a situação hermenêutica concreta em que se encontra. Se quiser compreender, deve relacionar o texto com essa situação. (GADAMER, 2003, p. 426, grifo nosso).

Portanto, 'aplicação', na hermenêutica filosófica, não significa o que em geral o senso comum pressupõe quando usa a mesma palavra, por exemplo, quando alguém se indaga: "Qual a aplicação de tais e tais conhecimentos na vida prática?". Quem assim se questiona pretende saber como certos conhecimentos podem lhe proporcionar benefícios práticos, ou talvez como eles podem resolver problemas profissionais. Os conhecimentos estabelecidos nas ciências naturais se sujeitam a tal exigência, uma vez que é possível "aplicá-los" para produzir coisas úteis a diversos setores da vida cotidiana. Porém, este significado comum de 'aplicação' pressupõe, na verdade, aquele outro significado da palavra na acepção da hermenêutica filosófica. Afinal, para "aplicar" certos conhecimentos, é necessário primeiro tê-los compreendido. 
Pois bem. Tais considerações gerais sobre a aplicação parecem ser suficientes para abordar o que realmente interessa aqui: expor as razões de Gadamer para caracterizar a hermenêutica como filosofia prática. Aqui, é indispensável fazer uma distinção bem simples, porém, fundamental, absolutamente fundamental, para compreender bem o problema, pois Gadamer a pressupõe constantemente, embora não pareça Ihe dar importância. Até aqui, a exposição se resumiu a apresentar o aspecto estruturador da coisa investigada na hermenêutica, a saber: a compreensão, ao passo que, a partir de agora, o foco incidirá muito mais sobre a própria investigação, a saber: a hermenêutica. Afinal, é ela a detentora do título de filosofia prática, não a compreensão! Só resta saber se ela realmente satisfaz os requisitos para merecer tal título.

O reconhecimento de tal distinção ajuda a ver melhor por que uma pressuposição geral de Gadamer, herdada de Aristóteles, é essencial para o argumento em favor da caracterização da hermenêutica como filosofia prática. Segundo Gadamer pressupõe, vale frisar: em consonância com o pensamento de Aristóteles, a estrutura ontológica da coisa investigada define o perfil teórico da investigação. Por exemplo, se algo se manifesta sempre e necessariamente da mesma maneira, o conhecimento sobre tal coisa tenderá a ser igualmente mais sólido. Afinal, a estabilidade ontológica de uma coisa possibilita saber não só como ela é mas também como será, de sorte que tal conhecimento assumirá universalidade e, até certo ponto, necessidade. ${ }^{5}$

Se tal pressuposição é mesmo uma herança de Aristóteles, onde Gadamer pode tê-la colhido? Parece haver uma única passagem, no livro I da Ética a Nicômacos, onde Aristóteles a enuncia com mais clareza:

\begin{abstract}
Nossa discussão será adequada se tiver a clareza compatível com o assunto, pois não se pode aspirar à mesma precisão em todas as discussões [...] As ações boas e justas parecem muito variadas e vagas [...] Falando de tais assuntos e partindo de tais premissas, devemos contentar-nos, então, com a apresentação da verdade sob forma rudimentar e sumária; quando falamos de coisas que são verdadeiras apenas em linhas gerais [...] não devemos aspirar a conclusões mais precisas. [...] os homens instruídos se caracterizam por buscar a precisão em cada classe de coisas somente até onde a natureza do assunto permite, da mesma forma que é insensato aceitar raciocínios apenas prováveis de um matemático e exigir de um orador demonstrações rigorosas. (ARISTÓTELES, 2001, p. 18, I 3 1094b-1095a, grifo nosso).
\end{abstract}

Em outras palavras, uma ciência como a matemática só pode ser exata, porque as coisas nela investigadas permitem tal exatidão, ao passo que, quando a coisa é a ação humana, por exemplo, semelhante exatidão já não é mais possível. Tal critério também deve valer para a hermenêutica: devido à peculiaridade ontológica da coisa nela investigada, a hermenêutica deve ser considerada uma filosofia prática. A ética se dedica a conhecer algo irredutivelmente relacionado 
a situações concretas, particulares; a ação de alguém só pode ser considerada justa ou injusta, por exemplo, quando é efetivamente praticada. Analogamente, a coisa investigada na hermenêutica, a compreensão, também só pode se resolver plenamente caso a caso, quando o intérprete aplica a si mesmo a verdade do que está interpretando em tal e tal ocasião.

A partir da comparação com a ética, não parece difícil ver como a aplicação também é o que fundamenta a caracterização da hermenêutica enquanto filosofia prática. É o que se torna ainda mais claro à luz da diferença entre a ética e as outras duas formas de conhecimento: a ciência e a técnica. De acordo com Gadamer, a crítica de Aristóteles à "generalidade vazia" à qual Platão reduz a ideia de bem confere à ética autonomia em relação à metafísica. Mas haveria uma razão para Platão confiná-la, a ética, no âmbito das formas imutáveis: ele pretendia preservar-lhe o estatuto de ciência e, para tanto, seria necessário protegê-la da possibilidade da mudança. Ironicamente, porém, a mutabilidade é a própria essência das coisas investigadas na ética e, portanto, Aristóteles a devolve, a ética, ao âmbito onde ela naturalmente se move.

Basicamente, a diferença entre coisas mutáveis e imutáveis, ou significativamente regulares, é o que fundamenta a diferença entre investigação simplesmente teórica e investigação prática. Basta considerar, conforme Gadamer (2003, p. 414) sugere, a matemática como parâmetro para ver como a inalterabilidade da coisa investigada possibilita, em uma teoria pura, a elaboração de demonstrações igualmente permanentes. Enquanto a investigação teórica apenas constata uma "constelação de fatos", a ética lida com coisas de natureza muito distinta. Por um lado, há a transitoriedade das circunstâncias onde alguém age e, por outro lado, a própria ação varia, pois o que ela revela a cada instante impele quem age a se transformar novamente.

Inspirado em Aristóteles, Gadamer define assim a coisa investigada na hermenêutica: "[...] também o problema hermenêutico se aparta evidentemente de um saber puro, separado do ser" (loc. cit.). A hermenêutica filosófica deve ser considerada filosofia prática, pois a coisa nela investigada, a compreensão, não conhece a tradição tal como um físico conhece as leis da natureza. Há um envolvimento entre intérprete e tradição que forçosamente impede tal pretensão de objetividade, aliás, um envolvimento semelhante àquele entre a ação e o contexto onde ela se realiza. Ademais, as condições de uma boa compreensão são tão vagas e variáveis quanto as condições de uma ação justa, já que elas só se definem em uma situação concreta.

É o que Gadamer diz em Hermenêutica como filosofia prática:

Neste âmbito propriamente dito da experiência hermenêutica, acerca de cujas condições uma filosofia hermenêutica tem que dar conta, confirma-se o parentesco próximo da hermenêutica com a filosofia prática. $E$, portanto, 
afirma-se o fato de que a compreensão - exatamente como a ação - é sempre um risco, e não permite a simples aplicação de um saber geral de regras para o entendimento de enunciados ou textos dados. (GADAMER, 1983, p. 74-75, grifo nosso).

Pois bem. Se a diferença entre investigação teórica e investigação prática Gadamer a considera "bem simples", a avaliação já não é tão segura assim quando se trata da diferença entre conhecimento prático e técnico. De fato, eles se assemelham em pontos fundamentais, por exemplo, ambos são conhecimentos circunstanciais, já que a ação e a técnica parecem partir do que thes parece correto ou incorreto em cada ocasião. Assim, o problema reside em saber se a ética não seria um conhecimento técnico, cuja finalidade consistiria em saber "como cada um deve produzir a si mesmo". O problema incide exatamente no significado da palavra 'produção', pois quem age deveria "produzir" a si mesmo tal como um artesão produz um instrumento.

Todavia, como Gadamer argumenta (2003, p. 416), ninguém dispõe de si mesmo tal como um artesão se vale do material com o qual trabalha; ninguém "produz a si mesmo" tal como produz um instrumento. A "consciência ética" se caracteriza por uma relação reflexiva, onde o conhecimento visa quem o elaborou; trata-se de saber-de-si (Sich-Wissen), ou ainda, de saber-para-si (Für-sichWissen). Assim também argumenta Aristóteles (2001, p. 120, 1141b) na Ética a Nicômacos: "O discernimento (phrónesis) também se identifica particularmente com a espécie de conhecimento relacionada com a própria pessoa [...] saber o que é bom para si mesmo [...]". É uma particularidade essencial da coisa investigada na ética, que a distingue da coisa visada no conhecimento teórico e da coisa visada no conhecimento técnico.

Ademais, seria possível elencar três diferenças principais entre conhecimento ético e conhecimento técnico, das quais a primeira diz respeito ao modo como se relacionam conhecimento e aplicação do conhecimento. A simples possibilidade de antever o uso para o qual se destina um instrumento permite ao conhecimento técnico definir previamente, e com alto grau de precisão, a forma da coisa a ser produzida. Todavia, não é possível delimitar antecipadamente diretrizes claras sobre como agir bem, de modo que elas pudessem ser registradas em um manual e, depois, ensinadas para quem quisesse aprendê-las. Como ser justo, por exemplo, é um conhecimento inextrincavelmente vinculado a uma ocasião oportuna e, portanto, não pode ser reduzido a regras prontas que poderiam ser aplicadas em quaisquer situações.

A segunda distinção concerne ao modo particular pelo qual conhecimento ético e conhecimento técnico relacionam meios e fins, e aqui sobressai mais claramente aquela relação reflexiva típica da sabedoria ética. Se alguém assimilou as técnicas necessárias para produzir uma coisa, então ele já sabe de antemão 
quais meios devem ser mobilizados na produção para que a coisa, uma vez produzida, conduza à finalidade desejada. Como lhe basta seguir uma técnica já assimilada, o artesão não precisa buscar em si mesmo conselhos úteis para produzir bem a coisa, o que não acontece com quem deseja agir corretamente. Aí a deliberação é imprescindível, ou seja, a reflexão sobre quais são os meios mais adequados ao fim desejado, já que não pode haver, como diz Gadamer (2003, p. 423), um "[emprego] dogmático da ética".

A terceira diferença se baseia em um aspecto particular da deliberação, que se revela no exercício da synesis, uma virtude análoga à sabedoria prática, à phrónesis. A synesis consiste na aptidão para "ser compreensivo" (Verständnis) com alguém e, assim como a phrónesis, ela também mobiliza aquele talento prático para deliberar sobre como agir em dada situação. Embora a synesis, diferentemente da phrónesis, não se relacione com a ação de quem está deliberando, mas sim com a ação de outro, ela também não é um conhecimento que pode ser "aplicado" invariavelmente a qualquer caso. Quem é compreensivo, argumenta Gadamer (2003, p. 425), não está objetivamente diante de alguém, mas, muito ao contrário, precisa deixar o outro afetá-lo conforme a ocasião, a ponto de se estabelecer entre eles uma afinidade íntima.

Essa última característica parece reunir os dois principais aspectos da sabedoria prática: a íntima imbricação com aquilo sobre o qual ela se põe a refletir e a necessidade de se concretizar somente na circunstância onde a ação se realiza. Tais aspectos também constituem a compreensão, uma vez que ela, assim como a phrónesis relativamente à ação, mantém um envolvimento igualmente íntimo com aquilo que busca conhecer, a tradição. Ademais, a compreensão também só se realiza como tal no momento em que aplica a si própria a verdade do discurso que a tradição lhe legou, assim como a phrónesis só faz o que lhe cabe na ocasião em que alguém deve agir bem. Ora, parece mesmo se evidenciar uma significativa afinidade entre as coisas investigadas na ética e na hermenêutica, entre a ação e a compreensão, respectivamente.

Enfim, convém retomar a pressuposição geral de Aristóteles segundo a qual o que define o perfil teórico de uma investigação é a natureza da coisa investigada. Se o que justifica a caracterização da ética como filosofia prática é a natureza da ação, então, dada a afinidade entre agir e compreender, por que não caracterizar a hermenêutica assim também? É o que, em resumo, argumenta Gadamer: a hermenêutica, graças à "estrutura aplicativa da compreensão, deve ser considerada filosofia prática! Entretanto, aqui, bem aqui, incide a minha dúvida: o que define a ética como filosofia prática é apenas a natureza da coisa nela investigada? Ela mesma, enquanto tal e tal investigação, não precisa satisfazer certas exigências para ser considerada filosofia prática, exigências tais que não dizem respeito diretamente à natureza da ação em si? 


\section{Por que a hermenêutica não pode ser considerada filosofia prática?}

Até aqui me empenhei para dar voz somente ao pensamento de Gadamer, e, para tanto, me privei de qualquer posicionamento crítico. Assim conduzi a exposição, a fim de evitar objeções muito comuns tais como: "Sua crítica se baseia em uma incompreensão do pensamento de Gadamer"; geralmente, junto com objeções semelhantes, ainda são feitas advertências como esta: "Você deveria ler com mais atenção tal e tal passagem de tal e tal obra". Aliás, se me permitem um breve parêntesis, quando se trata de criticar um filósofo estrangeiro, sobretudo, quando a tradição filosófica já o consagrou, aí parece haver uma resistência ainda maior para acolher qualquer posicionamento crítico contra ele. Seja como for, a seção anterior também procurou mostrar que eu não comecei a estudar hermenêutica há algumas poucas semanas.

Ademais, há uma razão filosófica para assumir uma postura passiva, ou melhor, mais expositiva, durante toda a segunda seção. A contundência de uma crítica só realiza a sua verdadeira finalidade - qual seja, abrir novas possibilidades de pensamento - caso ela tenha sido feita a partir de uma interpretação tão justa quanto possível da perspectiva criticada. Mas o que é uma interpretação justa? Bom, não pretendo abordar aqui algo tão multifacetado como o conceito de justiça, mas, por "interpretação justa", compreendo o cuidado de não atribuir a alguém um modo de pensar que não seja dele. Só um zelo sincero por tal cuidado pode conferir dignidade à objeção supracitada, pois a lamentável subserviência à consagração de certos filósofos é, no mínimo, inaptidão para assumir a própria maioridade, para dizê-lo com Kant.

Pois bem. Agora é necessário mudar a atitude, a fim de pôr à prova as pressuposições pelas quais Gadamer caracteriza a hermenêutica como filosofia prática. Em primeiro lugar, é importante retornar a Aristóteles, pois parece ter sido ele quem estabeleceu, pela primeira vez, a distinção entre investigação teórica e investigação prática. Mas não só. Embora seja também a referência fundamental de toda a argumentação de Gadamer, Aristóteles só parece ser importante para ele, porque Ihe legou aquela pressuposição tantas vezes evocada neste ensaio. Mas, eis o problema, Gadamer ignora outra razão de Aristóteles para caracterizar a ética como filosofia prática, sem a qual não seria possível consumar a diferença em relação à investigação teórica.

Como observei na seção anterior, devolver a ética ao "âmbito onde ela naturalmente se move" talvez tenha sido, comparada ao pensamento de Platão, a principal contribuição de Aristóteles àquilo que seria chamado de "filosofia prática". Como ele recomenda, a investigação precisa buscar clareza e precisão "compatíveis" com a coisa investigada, de sorte que, se ela, a coisa, é "verdadeira apenas em linhas gerais", seria "insensato" exigir da investigação um rigor 
matemático. Mas há ainda outra recomendação de Aristóteles que, porém, Gadamer a ignora, embora ela fosse, eis o problema, absolutamente decisiva para o seu projeto de fundamentar o caráter prático da hermenêutica filosófica. Eis a passagem onde Aristóteles a apresenta:

Sendo assim, já que a presente investigação não visa, como outras, ao conhecimento teórico (não estamos investigando apenas para conhecer o que é a excelência moral, e sim para nos tornarmos bons, pois se não fosse assim nossa investigação viria a ser inútil), cumpre-nos examinar a natureza das ações, ou seja, como devemos praticá-las. (ARISTÓTELES, 2001, p. 36, II 2, 1104a ss, grifo nosso).

Primeiramente, é imprescindível notar como tais observações também procuram diferenciar investigação teórica e investigação prática, mas sem apelar para o perfil ontológico da coisa investigada em cada uma delas. Ao contrário, Aristóteles enfoca a peculiaridade própria de cada investigação como tal: enquanto a investigação puramente teórica aspira conhecer apenas para conhecer, a investigação prática deve visar outra finalidade. Ela, a investigação prática, não aspira só o conhecimento em si mesmo do que seja a virtude ou, conforme a tradução, a "excelência moral", mas sim almeja "tornar bons" aqueles a quem se dirige. Mas por quê? Ora, porque, se assim não fosse, a investigação prática seria "inútil", palavra de Aristóteles!

Antes de prosseguir, convém rebater algumas possíveis objeções. Alguém poderia retrucar: "Por que você não recorreu ao livro VI? Afinal, aí Aristóteles desenvolve várias distinções nas quais Gadamer se baseia para caracterizar a hermenêutica como filosofia prática!". Porém, tal recomendação ignora algo crucial: as razões pelas quais alguém recorre a uma obra, em vez de outra. No meu caso, qual a finalidade aqui? Justificar, em concordância com Gadamer, a caracterização da hermenêutica como filosofia prática? Se assim fosse, de fato, talvez eu devesse me basear no livro VI. Todavia, a finalidade deste ensaio é discordar de Gadamer! Então, de que me valeria o livro VI? Por acaso, ele reforça o argumento defendido aqui segundo o qual uma filosofia prática deve ser útil à coisa nela investigada? Aparentemente, não.

Gadamer se interessa pelo livro VI da Ética a Nicômacos, porque ali Aristóteles distingue algumas "disposições da alma", a saber: a arte (technê), a ciência (episteme), o discernimento (phrónesis), a sabedoria filosófica (sophia) e a inteligência (noûs). Como já expus, essas diferenciações são importantes para Gadamer, uma vez que, por meio delas, ele pode comparar a coisa investigada na hermenêutica, a compreensão, com a coisa investigada na ética, a ação. Quem recomenda a leitura do livro VI ignora exatamente a distinção para a qual, com certa ênfase, eu chamei a atenção um pouco antes: a diferença entre investigação e coisa investigada. Portanto, convém reforçar: o que mais interessa ao 
argumento desenvolvido neste ensaio não é tanto a coisa investigada na ética, mas sim a própria ética enquanto investigação!

Ora, no livro VI, Aristóteles não tece qualquer consideração ou, pelo menos, nenhuma consideração relevante sobre as características distintivas da investigação chamada ética, à qual, a ela sim, cabe o título de "filosofia prática". Entretanto, o livro VI talvez possa ser útil aos propósitos deste ensaio, se o enfoque incidir naquelas "disposições da alma" com caráter investigativo e em contraste com as quais Aristóteles define o perfil da ética. Quais seriam elas? A ciência, a sabedoria filosófica e a inteligência, às quais cabe investigar coisas invariáveis. Para não incorrer em redundância e tornar o argumento mais preciso, seria melhor destacar uma "disposição", em particular: a sabedoria filosófica, sobre a qual Aristóteles observa:

[...] a sabedoria filosófica é uma combinação do conhecimento científico com a inteligência, que permite perceber o que há de mais sublime na natureza. Por isto dizemos que Anaxágoras, Tales e homens como eles têm sabedoria filosófica, mas não discernimento, quando vemos que eles ignoravam aquilo que lhes era vantajoso, e também dizemos que eles conheciam coisas extraordinárias, maravilhosas, difíceis e até divinas, mas inúteis, porque eles não procuravam os bens humanos. (ARISTÓTELES, 2001, p. 119, VI 7, 1141a, grifo nosso).

Mais adiante Aristóteles ainda complementa:

Pode haver dúvidas quanto à utilidade destas disposições da alma. Com efeito, a sabedoria filosófica não se preocupa com qualquer dos meios que contribuem para tornar um homem feliz, já que ela não indaga como as coisas passam a existir. (ARISTÓTELES, 2001, p. 124, VI 12, 1143b, grifo nosso).

A sabedoria filosófica investiga coisas "extraordinárias", diz Aristóteles, que, todavia, são "inúteis". Mas por quê? Ora, porque, prossegue Aristóteles, "eles [os filósofos] não procuravam os bens humanos". Consequentemente, quem busca os bens humanos lida com coisas úteis, correto? Pois bem. Se a investigação ética se recusasse a ser útil ao discernimento dos cidadãos, qual razão haveria para eles, interessados em coisas úteis, ouvirem o que a ética poderia Ihes dizer? Nenhuma! Não por acaso, Aristóteles se preocupa em definir a tarefa própria da ética: ser útil aos cidadãos, tarefa com base na qual é possível incluí-la, a ética, no gênero da filosofia prática! E ele o faz no livro I, já que parece ser muito mais apropriado definir o perfil da investigação a ser desenvolvida logo no início de uma obra, e não lá, no sexto livro.

Mas também cabe à conclusão de uma obra tecer considerações sobre o percurso traçado, a fim de verificar se a exposição feita alcançou a finalidade da investigação. Ora, não por acaso - repito: não por acaso - no livro X, Aristóteles 
volta a tecer considerações sobre a utilidade da investigação que ele está prestes a concluir. Aí, ele trata da eficácia das palavras para persuadir as pessoas a praticarem ações nobres, já que elas, as palavras, são os únicos meios de que dispõe uma investigação para persuadi-las. Contudo, Aristóteles (2001, p. 206) sabe bem com o que está lidando e não demora a concluir: as palavras "são impotentes para incitar a maioria das pessoas à prática da excelência moral". De novo, agora indiretamente, ele volta a reforçar a necessidade de a ética ser útil àqueles a quem ela se dirige, apesar dos seus limites:

Que palavras regenerariam tais pessoas? É difícil, senão impossível, remover mediante palavras hábitos há longo tempo incorporados ao caráter das pessoas. Talvez devamos considerar-nos felizes se conseguirmos dar-lhes uma aparência de excelência moral quando dispomos de todos os meios para influenciar as pessoas no sentido de torna-las boas. (ARISTÓTELES, 2001, p. $207, \times 9,1179 b$, grifo nosso).

O que significa usar de todos os meios para influenciar alguém a se tornar bom senão esforçar-se para ser-Ihe útil na difícil tarefa de ser um bom cidadão? Porém, o que Aristóteles diz sobre os limites da ética também parece valer para um debate filosófico. Como diria Schopenhauer, quando debatemos, não lidamos exatamente com a razão, mas muito mais com a vontade de alguém. Seja como for, há ainda um último recurso argumentativo. Recorro à interpretação de um historiador, embora considere suficiente a interpretação feita das passagens citadas da Ética a Nicômacos. Em História da filosofia antiga, Giovanni Reale ressalta justamente o que Aristóteles menciona no livro I acerca da característica específica da filosofia prática:

Na sistematização aristotélica do saber, depois das ciências teoréticas, em segundo lugar aparecem [...] as ciências práticas [grifo do autor]. Estas são hierarquicamente inferiores às primeiras, enquanto nelas o saber não é mais fim para si mesmo [grifo nosso] em sentido absoluto, mas subordinado e, em certo sentido, servo da atividade prática [grifo nosso]. Estas ciências práticas, de fato, dizem respeito à conduta dos homens, bem como ao fim que através dessa conduta eles querem alcançar [grifo nosso], seja enquanto indivíduos, seja enquanto fazendo parte de uma sociedade, sobretudo, da sociedade política. (REALE, 1997, p. 405).

Exatamente! O que torna prática uma investigação é também o compromisso com a sua utilidade para aqueles a quem ela se destina, no caso da investigação de Aristóteles, os cidadãos da pólis. Ela, a investigação, agora precisa servir a um propósito diferente dela mesma, caso queria cumprir a sua finalidade mais própria; em outras palavras, ela já não pode mais ser um fim em si 
mesma, a exemplo de uma investigação puramente teórica. Vale frisar: é exatamente tal compromisso em ser útil a alguém o que a caracteriza como uma investigação prática - e, sobretudo, é o que Gadamer curiosamente ignora quando busca caracterizar a hermenêutica como filosofia prática! Antes, ele até se empenha em livrar a hermenêutica de tal compromisso:

Não foi minha intenção desenvolver uma "doutrina da arte" do compreender, como pretendia ser a hermenêutica mais antiga. Não pretendia desenvolver um sistema de regras artificiais capaz de descrever o procedimento metodológico das ciências do espírito, ou que pudesse até guiá-lo. [...] Minha verdadeira intenção, porém, foi e continua sendo uma intenção filosófica: $o$ que está em questão não é o que fazemos, o que deveríamos fazer, mas o que nos acontece além do nosso querer e fazer. (GADAMER, 2003, p. 14, grifo nosso).

Decerto, o intuito de Gadamer é defender uma abordagem da hermenêutica que não seja confundida com o modo como a "hermenêutica mais antiga" a compreendia: como uma técnica de interpretação. Enquanto se dividia entre a teologia, a filologia e a jurisprudência, a hermenêutica visava a elaboração de regras úteis para quem enfrentasse o desafio de interpretar a Bíblia, os textos clássicos e as antigas leis. Apesar de ter sido responsável por unificar, pela primeira vez, a hermenêutica em uma só investigação, até mesmo Schleiermacher ainda a compreendia como uma técnica, embora a considerasse também uma arte. É o que ele (2000, p. 26, grifo nosso) revela ao estabelecer a finalidade da sua preleção sobre o conceito de hermenêutica: "[...] mostrar o caminho a uma juventude ávida de saber e lhe dar as diretivas [...]". 6

Gadamer, ao contrário, pretende conferir à hermenêutica um estatuto filosófico $^{7}$ e, para tanto, a desonerou justamente daquele compromisso característico de qualquer investigação prática: ser útil a alguém. É o que ele confessa em Hermenêutica como filosofia prática: "Não é meu intento solucionar qualquer situação prática do compreender" (id., 1983, p. 77). Assim, ao conferir à hermenêutica uma "intenção filosófica", Gadamer parece ter almejado torná-la uma investigação cujo propósito fosse ser um fim em si mesma, justamente o que não cabe a uma investigação prática. ${ }^{8}$ Em suma, a hermenêutica, para ser filosófica, não deve prescrever o que os outros "deveriam fazer", mas apenas descrever 0 que Ihes acontece quando compreendem:

[...] ela [a hermenêutica filosófica] descreve somente o que sempre sucede e especialmente sucede nos casos em que uma interpretação tem êxito e convence. Não se trata, pois, em nenhum caso, de uma teoria da arte que queira indicar como deveria ser a compreensão. (GADAMER, 1983, p. 76, grifo nosso). 
Ironicamente, quando a transforma em uma investigação tipicamente filosófica, Gadamer destitui a hermenêutica justamente daquilo que, depois, ele mesmo pretenderia lhe conferir: a possibilidade de ser uma investigação prática. Para enfraquecer os argumentos contra Gadamer até aqui desenvolvidos, alguém talvez pudesse retrucar: "Mas uma filosofia prática precisa mesmo assumir o compromisso de ser útil a alguém?". Ora, Aristóteles parece ter muita razão ao considerá-lo um aspecto determinante do próprio estatuto prático da investigação, pois de que valeria elaborar uma ética, se ela não pudesse orientar a ação de alguma maneira? Qualquer investigação digna de ser considerada prática, mesmo quando parece se distanciar completamente da ação concreta, precisa assumir tal compromisso, como até Kant o demonstra:

[...] para resolver de maneira mais curta e segura o problema de saber se uma promessa mentirosa é conforme ao dever, preciso só de perguntar a mim mesmo: - Ficaria eu satisfeito de ver a minha máxima (de tirar de apuros por meio de uma promessa não verdadeira) tomar o valor de lei universal (tanto para mim como para os outros)? [...] Em breve, reconheço que posso em verdade querer a mentira, mas que não posso querer a lei universal de mentir; pois, segundo uma tal lei, não poderia propriamente haver já promessa alguma, porque seria inútil afirmar a minha vontade relativamente às minhas futuras acções a pessoas que não acreditariam na minha afirmação [...]. (KANT, 1995, p. 34-35).

Ademais, se uma investigação prática visa examinar as ações humanas - e não parece haver outro escopo para tal exame senão as ações praticadas cotidianamente, muito estranho seria se ela, tal investigação, não lhes dissesse coisa alguma. Pois bem. Para lhes dizer algo realmente significativo, a investigação precisa aspirar aquilo que as ações também aspiram ou, pelo menos, deveriam aspirar, se a finalidade dos seres humanas for mesmo a vida em comunidade. Mas o que elas, investigação e ação, devem aspirar em comum? Em princípio, saber como agir bem, pois saber o que é uma ação boa parece ser bem diferente de saber como praticá-la. No primeiro caso, a investigação apresenta uma definição pura e simples da ação, ao passo que, no segundo caso, ela fornece uma orientação do que deve ser feito para praticá-la.

Ora, é bem o que Kant busca na passagem supracitada: depois de ter apresentado uma definição do que é o dever moral, ele fornece algumas orientações úteis para ajudar alguém a saber como se aproximar dele tanto quanto possível. Trata-se, suponho, de uma diferença simples, pois os aspectos definidores de uma coisa parecem ser bem diferentes dos meios pelos quais é possível realizá-la! Por exemplo, se couber uma analogia com a produção técnica, saber o que é uma mesa não me diz nada a respeito de como produzi-la assim 
como saber o que é a justiça não me mostra como ser justo. Assim, Kant reverbera a mesma posição em virtude da qual Aristóteles rompe conscientemente com Platão e Sócrates, conforme ele atesta na Ética eudemia:

Así Sócrates el Viejo pensaba que el fin [da ciência política] es conocer la virtud [...] pensaba que conocer la virtud y ser justo fueran coincidentes, pues tan pronto como hemos aprendido la geometría y la arquitectura, somos ya arquitectos y geómetras. Por eso inquiría qué es la virtud, pero no cómo o de qué cosas surge. [...] mientras que el fin de las ciencias productivas es otro que la ciencia y el conocimiento [...] respecto la virtud, no es lo más valioso saber qué es, sino de qué cosas procede. Pues no deseamos saber qué es la hombría, sino ser viriles. (ARISTÓTELES, 2009, p. 52, grifo nosso).

Enfim, a hermenêutica não pode ser filosofia prática, pois, quando lhe confere uma "intenção filosófica", Gadamer acaba Ihe enxertando aspectos definidores de uma investigação puramente teórica. Digo "enxertando", porque, até então, tais caracteres eram estranhos à "hermenêutica mais antiga", tradição onde ela vinha sendo considerada uma disciplina cujo fim era resolver problemas práticos da compreensão. Ora, o que define uma investigação teórica - conhecer apenas por conhecer - é incompatível com o que define uma investigação prática - comprometer-se em ser útil a algo diferente dela própria. Para concluir este ensaio, me resta esclarecer quais outras pressuposições do argumento de Gadamer precisam ser submetidas à crítica, para que as considere quem, por ventura, pretenda se dispor a defendê-lo.

\section{Três posicionamentos críticos contra três pressuposições de Gadamer}

Deixei bem claro, creio, como eu critico a primeira e mais importante pressuposição de Gadamer: a filiação da hermenêutica à filosofia prática com base no paralelo entre a coisa investigada na ética e a coisa investigada na hermenêutica. Porém, restariam duas outras pressuposições com as quais eu não me importaria, se não fosse a possibilidade de alguém evocá-las para defender Gadamer de algum modo. A segunda pressuposição me parece relativamente simples de compreender assim como a maneira como pretendo criticá-la, o que me motiva a apresentá-la primeiro. Já a terceira pressuposição é bem mais complexa, pois atinge o bojo do argumento de Gadamer: a possibilidade de a aplicação fundamentar o cunho prático da hermenêutica.

A crítica de Aristóteles ao "velho Sócrates", como o chama na Ética eudemia, esconde uma pressuposição que parece reverberar em um ensaio de Gadamer intitulado Entre fenomenologia e dialética. Lá, vale lembrar, Aristóteles (2009, p. 52, grifo nosso) diz: "Así Sócrates el Viejo pensaba que el fin [da ciência 
política] es conocer la virtud [...] pensaba que conocer la virtud y ser justo fueran coincidentes". Depois, a fim de retratar melhor a perspectiva do antigo mestre de Platão, ele ainda lembra da comparação com a arquitetura e a geometria, cuja aprendizagem bastaria, segundo Sócrates, para já se tornar arquiteto ou geômetra. Porém, a situação da ética é bem outra, Aristóteles retruca, já que conhecer a virtude não basta para já ser alguém virtuoso, ou seja, a teoria acerca da prática não coincide com a própria sabedoria prática!

Aí se concentra basicamente todo o drama da ética, com o qual Aristóteles, a propósito, conclui a Ética a Nicômacos:

Se estes assuntos e a excelência moral e intelectual, bem como a amizade e o prazer, foram suficientemente examinados em suas linhas gerais, podemos supor que nossa investigação atingiu o seu objetivo? Ou talvez, como tivemos a oportunidade de dizer, ${ }^{9}$ nas ciências práticas o objetivo não é chegar a um conhecimento teórico dos vários assuntos, e sim por em prática as nossas teorias? Se for assim, saber o que é a excelência moral [areté] e a intelectual não é o bastante; devemos esforçar-nos por possuí-las e praticá-las, ou experimentar qualquer outro meio existente para nos tornarmos bons. (ARISTÓTELES, 2001, p. 206, X 9 1179a-1179b, grifo nosso).

Mais adiante, ele ainda observa:

Se as palavras bastassem para tornar-nos bons, elas teriam com justiça obtido grandes recompensas [...] e deveríamos ter as palavras sempre à nossa disposição; mas sendo as coisas como são, apesar de as palavras terem o poder de encorajar e estimular os jovens de espírito generoso, e, diante de uma nobreza inata de caráter e de um amor autêntico ao que é nobilitante, ser capazes de torná-los susceptíveis à excelência moral, elas são impotentes para incitar a maioria das pessoas à prática da excelência moral [areté]. (Loc. cit.).

Enfim, a pressuposição de Aristóteles segundo a qual uma teoria sobre a ação não coincide com a própria sabedoria mobilizada na ação é o que ecoa no supracitado ensaio de Gadamer. Ela aparece em um contexto onde Gadamer critica quem defende a possibilidade de a ciência "substituir a razão prática", quando o problema consiste em saber como utilizar o conhecimento científico. Não me interessa aqui expor o argumento de Gadamer contra quem defende tal atribuição de responsabilidade à ciência, mas sim a comparação feita, logo depois, entre a filosofia prática e a hermenêutica. Assim como a filosofia prática não é ela mesma a "racionalidade" mobilizada na ação, diz Gadamer, a hermenêutica também não é a "arte de compreender":

Ora, a filosofia prática não é certamente, ela própria, esta racionalidade [prática]. Ela é filosofia, isto é, uma reflexão, e uma reflexão sobre aquilo que 
deve ser a configuração da vida humana. No mesmo sentido, a hermenêutica filosófica não é ela própria a arte do compreender, mas a sua teoria. (GADAMER, 2004, p. 33-34, grifo nosso).

Qual seria, então, a minha crítica? Ora, se enseja aqui, conforme a passagem citada evidencia, aquela pressuposição de Aristóteles segundo a qual a teoria acerca da ação virtuosa não coincide com a própria ação virtuosa. Então, Gadamer, para reforçar o paralelo entre hermenêutica e ética, não hesita em comparar: a hermenêutica também não seria ela própria "arte de compreender", mas apenas uma investigação teórica sobre ela. Contudo, sem notar, ao transpor para a hermenêutica aquela pressuposição de Aristóteles, Gadamer contradiz a sua própria tese sobre a universalidade da compreensão. Se a hermenêutica não é "arte da compreensão", então alguma coisa não é compreensão, a saber, a própria hermenêutica enquanto tal e tal teoria!

Talvez, alguém pudesse fazer uma distinção sutil, a fim de defender a comparação de Gadamer: "Mas ele se refere claramente à 'arte da compreensão', e não à compreensão em si, que é aquilo sobre o qual a hermenêutica teoriza". A sutileza aqui consiste em indicar uma suposta diferença entre o que faz a "arte de compreender" e o que faz a hermenêutica filosófica. Enquanto a primeira se dedica a descobrir os meios para compreender bem discursos em geral, a segunda seria uma investigação sobre as condições em virtude das quais tal compreensão é possível. Portanto, valeria a comparação: assim como a filosofia prática não é o próprio exercício da racionalidade prática, não cabe à hermenêutica em si exercitar a "arte da compreensão".

Contudo, convém retornar à passagem citada, já que parece ser absolutamente relevante ressaltar a expressão pela qual Gadamer indica como ele compara filosofia prática e hermenêutica: "no mesmo sentido", diz ele. Em outras palavras, "no mesmo sentido" em que a filosofia prática não é a racionalidade prática, a hermenêutica não seria um exercício da boa compreensão de discursos, mas antes só uma "teoria" sobre como ele seria possível. Todavia, não consigo imaginar como a hermenêutica poderia fazer o que ela faz sem mobilizar a mesma "racionalidade" exercitada na "arte da compreensão", a saber, a própria compreensão! Ora, a relação entre filosofia prática e ação não se efetua "no mesmo sentido", pois, para investigá-la teoricamente, a filosofia prática não parece mobilizar a racionalidade prática, a phrónesis.

Tais considerações sobre a segunda pressuposição de Gadamer me parecem suficientes e, portanto, passo à exposição da terceira, aquela segundo a qual a investigação teórica e a investigação prática seriam atitudes mutuamente excludentes. Mas, alguém poderia se perguntar, Gadamer a pressupõe? Sem dúvida! Mais uma vez, em Hermenêutica como filosofia prática, ele (1983, p. $76)^{10}$ define a "prioridade da teoria" por meio da "eliminação de todo interesse 
utilitário", ou seja, por meio da negação do que define uma investigação prática. Para quem ainda não estiver convencido, lembro ainda a maneira pela qual Gadamer torna filosófica a hermenêutica - negando-Ihe o compromisso de ser útil para resolver os problemas da compreensão!

Pois bem. Então, por que seria um problema para Gadamer partir da pressuposição segundo a qual a investigação teórica exclui de si, por definição, o aspecto característico da investigação prática? Ora, porque, segundo ele, a compreensão é uma experiência universal, haja vista a sua famosa proposição: "o ser que pode ser compreendido é linguagem" (GADAMER, 2003, p. 612). Como assim? Linguagem e compreensão mantêm uma relação estreita, tão estreita que, se algo adentra no âmbito da linguagem, adentra também no âmbito da compreensão. Ademais, a linguagem, para Gadamer, é universal, ${ }^{11}$ o que significa: nada pode vir a ser para o ser humano sem imediatamente se encontrar nas possibilidades do discurso e, portanto, da compreensão.

Tudo bem, mas qual é o problema? Primeiro, é preciso ver bem uma consequência importante: se a compreensão é tão universal quanto a linguagem, então a investigação teórica e a investigação prática não podem ser outra coisa senão formas de compreensão. Certo? Contudo, e aqui, bem aqui, principia todo o problema, elas são investigações mutuamente excludentes, pois, como busquei mostrar, para ser puramente teórica, uma investigação não pode desejar ser útil a ninguém. Negar tal compromisso é o que confere pureza a uma investigação! Enfim, há duas maneiras, mutuamente excludentes, pelas quais a compreensão pode se realizar: ou sob a forma de uma investigação puramente teórica ou sob a forma de uma investigação prática.

Portanto, a coisa investigada na hermenêutica, a saber, a compreensão, acaba revelando uma natureza híbrida - sob certo aspecto ela pode ser prática, mas sob outro aspecto ela pode não ser. Logo, haja vista a pressuposição herdada de Aristóteles segundo a qual o que define o perfil teórico de uma investigação é a natureza da coisa investigada, então a hermenêutica não pode ser mesmo filosofia prática! Ela não pode esperar da coisa, a compreensão, aquelas determinações pelas quais ela poderia se definir como filosofia prática, visto que a compreensão pode não ser uma experiência prática. Entretanto, a aplicação não poderia salvá-la do problema? Não! - e assim chego à consequência mais importante de todas as considerações já feitas.

Aqui, o problema apresentado atinge em cheio, suponho, o cerne da hermenêutica filosófica. Afinal, conforme Gadamer (2003, p. 426) mesmo observa, vale lembrar, a aplicação "não é uma parte última, suplementar e ocasional do fenômeno da compreensão, mas o determina desde o princípio e no seu todo". Mesmo assim, Gadamer jamais poderia esperar da aplicação uma resposta satisfatória ao problema apresentado. A razão é muito simples. A aplicação pode muito bem estruturar a compreensão mesmo quando ela se realiza sob a forma 
de uma investigação puramente teórica, ou seja, sem qualquer vestígio prático. Portanto, a aplicação não pode proporcionar à compreensão os aspectos necessários para torná-la uma experiência plenamente prática.

Mais especificamente, basta examinar o que ocorre no exercício de uma investigação puramente teórica. Um filósofo pode muito bem ler os clássicos da tradição e, a fim de compreendê-los bem, ver as coisas sobre as quais eles discorrem tal como eles as consideram verdadeiras. Para tanto, tal filósofo em nenhum momento precisaria assumir o compromisso de ser útil a quem quisesse resolver algum problema prático da vida; ele poderia muito bem se manter indiferente a tudo, e permanecer absorto na contemplação de fenômenos completamente "abstratos", por assim dizer. Em poucas palavras, a aplicação nunca pôde proporcionar à hermenêutica aquilo que Gadamer esperava para considerá-la, a hermenêutica, uma filosofia prática.

Mas, vale dizer, não se trata de um problema estrutural da compreensão, pois ela, sob outra perspectiva, poderia muito bem esperar da hermenêutica orientações úteis sobre como interpretar bem um discurso. É a hermenêutica filosófica, tal como Gadamer a concebe, quem se recusa a satisfazer as expectativas práticas da compreensão, só porque ela, a hermenêutica, almeja o título de investigação meramente filosófica! Sob a perspectiva de Gadamer, aquilo que se encarrega de estruturar a compreensão "põe entre parêntesis" qualquer preocupação prática; sob a tutela da aplicação, já não importa se a compreensão está sendo realizada bem ou mal, mas apenas o seguinte fato: ela faz valer, caso a caso, as "verdades" oriundas da tradição. Ponto!

Enfim, eis quase tudo o que eu poderia argumentar contra a possibilidade de a hermenêutica ser considerada uma filosofia prática. Primeiro, a coisa em si mesma não basta para lhe proporcionar tal estatuto, visto que uma investigação prática ela própria só se torna realmente prática quando assume o compromisso de ser útil a alguém. Segundo, mesmo se a coisa pudesse fazê-lo por si, a hibridez da compreensão não o permitiria, já que ela pode ser experimentada de dois modos mutuamente excludentes: ou como investigação prática ou como investigação puramente teórica. Terceiro, que a aplicação estruture a compreensão não é suficiente para torná-la, a compreensão, uma atividade prática, ao contrário do que Gadamer pressupõe.

\section{É possível defender Gadamer?}

Às vezes, penso, filosofia e advocacia parecem compartilhar uma situação muito semelhante, se não idêntica: para elas, não parece haver causas impossíveis! Alguém sempre pode redefinir conceitos fulcrais em um argumento, a fim de neutralizá-lo: "Basta compreender tal e tal conceito de outra maneira e - 
pronto! - toda a argumentação se anula". Há quem recorra também a uma acusação desonesta: "Seu argumento só vale para a maneira como você compreende 'Gadamer", ou ainda: "Você elabora um modo específico de interpretá-lo, e só assim o argumento vale". Digo "desonesta", porque, em tais casos, não são apresentados contra-argumentos, mas apenas uma resignação, uma desqualificação gratuita do esforço realizado.

Seja como for, eu poderia expor aqui algumas tentativas já feitas em defesa de Gadamer, mas, para tanto, alguém já deveria ter notado o problema. Até onde sei, ninguém ainda o percebeu e, portanto, não há quem tenha se prontificado a elaborar uma defesa. Sem dúvida, há artigos publicados sobre hermenêutica e filosofia prática. Por exemplo, Gadamer e a leitura heideggeriana de Aristóteles, de Gustavo Silvano (2014), e Hermenêutica filosófica como filosofia prática, de Viviane Magalhães (2015). Porém, eles parecem muito mais partir da perspectiva segundo o qual a hermenêutica seria, sim, uma filosofia prática; não só partem dela como também não parecem apresentar algum novo aspecto que pudesse ensejar uma possível defesa.

Contudo, em sua dissertação de mestrado, Gustavo (2007, p. 78) defende uma conclusão digna de nota, baseada, a propósito, no ensaio de Gadamer (1983, p. 41ss) O que é práxis? As condições da razão social. A exemplo do que Gadamer propõe ali, Gustavo (2007, p. 78) arremata: a solidariedade seria "algo sempre e já em atividade no processar compreensivo". Bom, se assim fosse, de fato, a compreensão seria mesmo uma atividade perfeitamente prática. Aliás, tão perfeita que não seria sequer necessário se esforçar para ser solidário, ${ }^{12}$ uma vez que, enquanto a compreensão for um modo de ser, ${ }^{13}$ a solidariedade já seria um aspecto da própria estrutura ontológica dos seres humanos. Logo, em um debate, não faria mais sentido se preocupar com a honestidade intelectual dos interlocutores, afinal, todos são solidários.

Enfim, está feito! Não me parece necessário fazer as vezes de outra pessoa para estabelecer um diálogo em torno do problema apresentado aqui. Se algum dia alguém ler este ensaio, já saiba de antemão da minha predisposição para discuti-lo. A propósito, para a filosofia florescer de vez no Brasil, faltam principalmente duas coisas, creio: 1) disposição para pensar por si mesmo, e 2) fôlego para discutir, argumentar. Em geral, foi o que formou uma tradição filosófica na Europa. Parmênides discordou de Heráclito; Aristóteles, de Platão; Kant, de Hume; Nietzsche, de Schopenhauer etc. Tal diálogo tão profícuo só foi possível, porque nenhum deles encarou a tradição como um texto só para comentar, mas como uma oportunidade para pensar.

\section{Referências bibliográficas}


ARISTÓTELES. Ética a Nicômacos. 4. ed. Brasília: Editora Universidade de Brasília, 2001.

. Ética eudemia. 1. reimpr. Madrid: Alianza Editorial, 2009.

BACK, Rainri. Distanciamento teórico e engajamento prático: acerca da unidade entre atitude teórica e atitude prática a partir de um problema oriundo da hermenêutica filosófica. 2013. 303 f. Tese (Doutorado em Filosofia) - Instituto de Filosofia e Ciências Humanas, Universidade do Estado do Rio de Janeiro, Rio de Janeiro, 2013.

GADAMER, Hans-Georg. A razão na época da ciência. Rio de Janeiro: Tempo Brasileiro, 1983.

- Verdade e método l: traços fundamentais de uma hermenêutica filosófica. 5. ed. rev. Petrópolis, RJ: Vozes; Bragança Paulista, SP: Universitária São Francisco, 2003.

. Verdade e método II: complementos e índice. 2. ed. Petrópolis, RJ: Vozes; Bragança Paulista, SP: Universitária São Francisco, 2004.

HEIDEGGER, Martin. Ser e tempo. parte I. 12. ed. Petrópolis, RJ: Editora Vozes, 2002.

KANT, Immanuel. Fundamentação da metafísica dos costumes. Lisboa: Edições 70, 1995.

MAGALHÃES, Viviane. Hermenêutica filosófica como filosofia prática. Ekstasis: revista de hermenêutica e fenomenologia, Rio de Janeiro, v. 4, n. 1, p. 38-52, jan./jun. 2015.

REALE, Giovanni. História da filosofia antiga. v. II. 1. reimpr. São Paulo: Edições Loyola, 1997.

SCHLEIERMACHER, Friedrich. Hermenêutica: arte e técnica de interpretação. 2. ed. Petrópolis, RJ: Vozes, 2000.

SILVANO, Gustavo. Gadamer e a leitura heideggeriana de Aristóteles. Peri: Revista de Filosofia, Santa Catarina, v. 6, n. 1, p. 118-125, jan./jun. 2014.

STEIN, Ernildo. É a hermenêutica filosófica filosofia? Filosofia UNISINOS. v. 3. 


\section{n. 4. Rio Grande do Sul, jan/jun, 2002, p. 65-85.}

${ }^{1}$ De fato, a fenomenologia de Husserl, da qual Heidegger é herdeiro inequívoco, visa apresentar uma solução para o problema da validade do conhecimento. Todavia, para que a "filosofia hermenêutica" de Heidegger pertença "à tradição da fenomenologia", não parece ser necessário que ela também vise o problema do conhecimento, como Stein pressupõe (ibid., p. 82-83).

${ }^{2}$ O que me parece duvidoso, mas não é importante discuti-lo aqui. De fato, em Ser e tempo, em particular, no parágrafo §13, Heidegger (2002, p. 98ss) se dedica ao problema do conhecimento, quando ele procura mostrar como ele, o conhecimento, se funda na constituição ontológica do ser-aí chamada "ser-no-mundo". Mas admiti-lo está muito longe, creio, da interpretação segundo a qual a motivação de Heidegger para escrever Ser e tempo é o problema do conhecimento.

${ }^{3}$ É o que Stein parece pressupor em seu artigo. Se assim fosse, caberia perguntar: Deleuze, Derrida, Foucault, Lévinas e tantos outros se motivaram fundamentalmente pelo problema do conhecimento? Caso a resposta seja negativa, então o que eles apresentaram não seria filosofia? Obviamente, eles até podem responder a questões relativas ao conhecimento, mas não parece correto considerá-los "teóricos do conhecimento", em sentido estrito, tal como Husserl apresentava a si mesmo.

${ }^{4}$ Um esclarecimento terminológico: 'experiência hermenêutica' e 'experiência da compreensão' podem ser consideradas expressões sinônimas neste ensaio. A fim de apresentar uma definição ao menos provisória, compreendo aqui por 'experiência' as transformações possíveis e constantes no modo como alguém compreende uma coisa, graças às quais a própria coisa passa a se manifestar de uma maneira diferente, embora se trate da mesma coisa até então compreendida.

${ }^{5}$ Digo "até certo ponto", porque conhecimento e coisa jamais coincidem. Se fosse possível tal coincidência, aí sim haveria um conhecimento inume a revisões e, portanto, necessário. Algo assim, porém, me parece inaceitável, embora algumas pessoas pareçam crer em tal possibilidade. Mas tal crença, segundo penso, seria só uma espécie de "fé" em algo apenas logicamente provável.

${ }^{6}$ Em outro momento, Schleiermacher ainda observa: "Agora, se a rapidez do êxito decresce depois dos primeiros começos, então, a reflexão encontra-se favorecida pela maior lentidão dos movimentos e a demora mais prolongada em uma mesma operação, e somente então começa aquele período onde as experiências hermenêuticas são reunidas, e reunidas como conselhos, pois eu prefiro dizer esta palavra do que regras" (ibid., p. 46, grifo nosso).

${ }^{7}$ A propósito, em seu artigo, o prof. Ernildo Stein não faz sequer um comentário a essa passagem, tão importante para o projeto de Gadamer de inaugurar uma hermenêutica filosófica. Logo, a compreensão do prof. Stein do que seja uma hermenêutica filosófica acaba se revelando insuficiente, o que, por conseguinte, fragiliza o seu argumento.

${ }^{8}$ Ser um fim em si mesmo é exatamente o que diferencia as ciências teoréticas e as ciências práticas, como Giovanni Reale observa: "Na sistematização aristotélica do saber, depois das ciências teoréticas, em segundo lugar aparecem [...] as ciências práticas. Estas são hierarquicamente inferiores às primeiras, enquanto nelas o saber não é mais fim em si mesmo em sentido absoluto, mas subordinado e, em certo sentido, servo da atividade prática" (REALE, 1997, p. 405, grifo do autor).

${ }^{9}$ Trata-se, sem dúvida alguma, de uma referência àquela passagem já citada, onde Aristóteles estabelece a diferença entre o conhecimento meramente teórico e as "ciências práticas", em que, vale frisar, estas últimas, ao contrário daquelas, precisam ser úteis àquilo sobre o qual versam, a ação. Cf. ARISTÓTELES, 2001, p. 36, II 2, 1104a ss.

${ }^{10}$ Para quem é mais cético, eis o trecho completo: "Dedicar a vida a interesses teóricos pressupõe a virtude da phrónesis. Porém, isto não limita, de modo algum, a prioridade da teoria, isto é, o interesse do mero querer saber. Sua ideia é, e continua sendo, a eliminação de todo interesse utilitário, quer essa utilidade se refira ao indivíduo, a um grupo, ou a toda a sociedade" (GADAMER, 1983, p. 76). O primeiro período da citação poderia muito bem animar aqueles que, a despeito dos argumentos apresentados neste ensaio, ainda assim, resistem a admitir as minhas críticas a Gadamer. Porém, convido-os a ler uma parte da minha tese de doutoramento Distanciamento teórico e engajamento prático, a seção 1.5, intitulada "Possíveis réplicas". Ali mostro como tal afirmação de Gadamer não o previne das consequências oriundas da maneira como ele, no trecho citado, define a "prioridade da teoria".

${ }^{11}$ Aqui, remeto-os aos ensaios Homem e linguagem e Até que ponto a linguagem prescreve o pensamento, in GADAMER, 2004, p. 173-182, 234-242, respectivamente.

Problemata: R. Intern. Fil. v. 8. n. 3 (2017), p. 78-102

ISSN 2236-8612 
${ }^{12}$ Caso a solidariedade possa ser considerada uma virtude ética, o que me parece perfeitamente plausível. ${ }^{13}$ Gadamer a concebe assim, inspirado em Heidegger. 